\title{
Psikiyatri Hemşireleri Tarafından Şizofreni Tanılı Hastalara Uygulanan Psikososyal Rehabilitasyon Programları: Sistematik Derleme
}

\section{Psychosocial Rehabilitation Programs Applied to Patients with Schizophrenia by Psychiatric Nurses: Systematic Review}

Mahinur Betül Çalışkan ${ }^{1} \mathbb{D}_{L}$ Elvan Emine Ata $2 \mathbb{D}_{L}$ Gül Dikeç ${ }^{2} \mathbb{D}$

\begin{abstract}
$\ddot{0 z}$
Bu derlemenin amacı, psikiyatri hemşireleri tarafindan şizofreni tanılı hastalara uygulanan psikososyal rehabilitasyon programları ile ilgili çalışmaları gözden geçirmektir. Bu çalışmada, 15-31 Mayıs 2019 tarihleri arasında Türk Psikiyatri Dizini (1) ve Pubmed (7) veri tabanları taranarak 2008-2019 yılları arasında yayınlanan 8 nicel çalışma ele alındı. Makaleler incelenirken, raporlama özelliklerinin değerlendirilmesinde 27 maddeli PRISMA Bildirimi kullanıldı. Sistematik tarama sonucunda 8 makaleye ait bulgular/ sonuçlar çizelge olarak sunuldu. Yayınlanan çalışmalarda, psikiyatri hemşireleri tarafindan şizofreni tanılı hastalara uygulanan psikososyal rehabilitasyon programlarının; duygusal ifadenin geliştirilmesine yönelik eğitimler, duygu tanımanın yer aldığı bilişim teknolojileri uygulamaları, taburculuk sonrasını kapsayan psikoeğitimler, isi̧itsel halüsinasyon semptom yönetim programı, müzik terapisi ve ev ziyaretleri olduğu saptandı. Ayrıca yapılan çalışmalarda; söz konusu psikososyal rehabilitasyon programları ile hastaların sosyal-bilişsel işlevsellik, yaşam kalitesi ve ilaç uyumunda artma, hastanede yatı̧ süresinde ve nükslerde azalma, işitsel halüsinasyonlarla baş edebilme, duygu tanımalarında iyileşme gibi pek çok olumlu etkileri olduğu belirlendi. Yapılan çalışmalarda şizofreni tanılı hastaların psikososyal rehabilitasyonunda psikiyatri hemşireleri tarafından yapılan sınırlı sayıda çalışmanın olduğu, psikiyatri hemşirelerinin rehabilitasyon alanında yaptıkları girişimlerin sonuçlarının değerlendirildiği çalışmalara ihtiyaç olduğu saptand.
\end{abstract}

Anahtar sözcükler: Şizofreni, psikososyal rehabilitasyon, psikiyatri hemşireliği

\section{Abstract}

The purpose of this review is to review the studies related to psychosocial rehabilitation programs applied by psychiatric nurses to patients diagnosed with schizophrenia. The study was conducted on the Turkish Psychiatric Index (1) and Pubmed (7) databases between 15-31 May 2019 and 8 quantitative studies published between 2008-2019. The 27-item PRISMA Statement was used to evaluate the reporting characteristics. In this review which was written as a result of systematic screening, findings/results of 8 articles were presented as tables. In published studies, psychosocial rehabilitation programs which applied by psychiatric nurses to patients with schizophrenia; it was determined that there were trainings aimed at improving emotional expression, information technology programs including emotional recognition, psychoeducation programs after discharge, Auditory Hallucinatory symptom management program, music therapy and home visits. Also in the studies; with these psychosocial rehabilitation programs, it was determined that patients had many positive effects such as increase in social-cognitive functionality, quality of life and adherence, decrease in hospital stay and relapse, coping with Auditory Hallucinations, and improvement in emotional recognition. In the studies, it was found that there are limited number of studies conducted by psychiatric nurses in the psychosocial rehabilitation of the patient with schizophrenia and it is necessary to evaluate the results of the interventions performed by psychiatric nurses in this field.

Keywords: Schizophrenia, psychosocial rehabilitation, psychiatric nursing

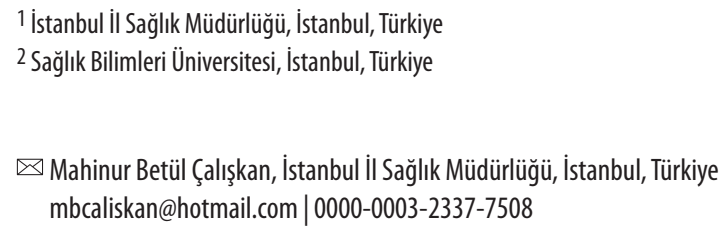

Received/Geliş tarihi: 29.04.2020| Kabul tarihi/Accepted: 24.08.2020|Çevrimiçi yayın/Published online: 21.12.2020 
ŞiZOFRENI; genç yaşta başlayan, her iki cinsiyette de eşit olarak görülen ve her toplumda ortaya çıkabilen, özellikle düşünce, algı ve duygulanım alanlarında bozulmalarla, iyileşme ve yinelemelerle seyreden süreğen bir hastalıktır. Kişinin davranışsal, düşünsel, algısal ve duygusal alanlarda daha önce gösterdiğgi olağan işlevselliğin dışında, gerçeklerle bağdaşmayan bir işlevselliğe geçtiği bu hastalık, kişilerin önemli bir kısmında bireysel ve sosyal işleyişi tahrip etmenin yanı sıra, ruhsal ve toplumsal yeti yitimine de neden olmaktadır (Yıldız 2005, Os ve Kapur 2009). Toplumda görülme oran $\% 1$ olan şizofreni dünyada 50 milyondan fazla kişiyi etkileyen bir ruhsal hastalıktır (Mitra ve ark. 2017).

Psikiyatrik hastalıkların tedavisinde kullanılan antipsikotik ilaçların 1950'lerde keşfedilmesi; hastanede kalıs sürelerinin kısalması ve hastaların erken taburcu edilmeleri gibi önemli gelişmelere neden olmuştur (Üstün ve ark. 2018). Ancak tek başına ilaç tedavisinin psikotik bozukluğu olan bireylerin yaşam kalitesini bozan relapsları önlemede yetersiz kaldığ bilinmektedir (Doğan ve ark. 2002, Hogarty ve ark. 2004). İlaç tedavisinin şizofreni tanılı bireyin topluma yeniden uyumunu sağlamada, kişiler arası ilişkilerini geliştirmede ve öz bakım aktivitelerini artırmada etkisi sınırlıdır. Bu nedenle şizofreni tedavisinde kullanılan antipsikotik ilaçların tedavinin vazgeçilmez bir unsuru olduğu, ilaç tedavisinin sosyal destek programları, beceri eğitimi ve çeşitli psikososyal yaklaşım programları ile ele alınmasının gerekli olduğu vurgulanmaktadır (Akpınar ve Kelleci 2008).

Psikiyatrik rehabilitasyon çalışmaları ruhsal bozukluğu olan hastalarda yeti yitiminin azaltılmasına, ruhsal, toplumsal ve mesleki işlevselliğin artırılmasına, yaşam doyumu ile kalitesinin yükseltilmesine odaklanmaktadır. Hastaların hasta kimlikleri dı̧̧ında toplumsal bir birey olabilmelerini sağlamak rehabilitasyonun temel amaçlarından biridir (Yıldız ve ark. 2003). Şizofrenide psikiyatrik uyumlandırma girişimleri ile hastalığı olan kişinin negatif belirtilerinde iyileşmeyi sağlamak, bağımsız yaşayabilmesi için toplumsal ve mesleksel becerilerini geliştirmek, hastalıkla başa çıma becerilerini artırmak, içgörü kazanımı ile tedaviye uyum sağlanarak hastaneye yatış sıklı̆̆ını azaltmak, tüm bunların neticesinde de maliyette düşüş hedeflenmektedir (Özdemir ve ark. 2017). Şizofreni tanilı hastalarda kişiler arası ilişkilerin geliştirilmesi, hastaların toplumun bağımsız üyeleri olarak yaşayabilmeleri amacıyla uygun sosyal tepkiler gösterme yeteneklerini artırma, kaybettikleri yetileri kazandırma, hastaneye yatı̧s sayılarını azaltmanın yanı sıra relapsları önlemek gibi pek çok amaç için psikiyatrik rehabilitasyon programları uygulanmaktadır (Hutchison ve ark. 2017).

Yukarıda belirtilen hedeflere ulaşmak için şizofreni ve psikotik bozukluk tanısı alan bireyler için dünyada ve ülkemizde sağlık profesyonelleri tarafindan birçok rehabilitasyon programı uygulanmaktadır. Uygulanan programlarda çoğunlukla psikoeğitim, beceri eğitimi, iş-uğraş terapileri, egzersiz yapma, beslenmenin düzenlenmesi ve hijyenik gereksinimleri karşılama gibi sağlıklı yaşam biçimini destekleyen uygulamalar, öz bakım becerilerinin geliştirilmesi, ortam terapisi, psikoterapiler ve sosyal etkinlikler gibi uygulamaları içermektedir. Bu doğrultuda ülkemizde psikososyal beceri eğitimi programı, topluma yeniden katılım programı ve mesleki rehabilitasyon programları uygulanmaktadır (Yazıcı 2001, Doğan ve ark. 2002, Yıldız ve ark. 2002, Yı1dız 2005, Çetinkaya Duman ve ark. 2007, Morin ve Franck 2017). Yürütülen çalışmaların çoğu toplum ruh sağllğı merkezleri, gündüz 
hastaneleri, dernekler ve psikiyatri klinikleri gibi alanlarda yürütülmüştür. Çalışmaların sonuçları değerlendirildiğinde ise hastaların rehabilitasyon programından yarar gördükleri ve işlevselliklerinin arttığı ifade edilmektedir (Arslan ve ark. 2015).

Rehabilitasyon programları hastanın işlevselliğini artırırken bir yandan da sağlık bakım maliyetlerini de azaltan bir uygulama olarak da karşımıza çıkmaktadır Kopelowicz ve ark,'nın (2012) yapmış oldukları çalışmada; yakın zamanda psikotik semptomları alevlenmiş ve ilaç uyumu olmayan şizofreni tanılı hastalar ile ailelerine uygulanan psikiyatrik uyumlandırma girişiminin hastaneye yatı̧̧ oranlarını düşürdüğü belirtilmektedir (Kopelowicz ve ark. 2012). Kerkemeyer ve ark.'nın (2018) Almanya'da şizofreni tanılı hastalara uygulanan entegre bakım programının etkinliğini ve maliyet analizini değerlendirmek amacıyla yapmış oldukları çalışmalarında; uygulanan program sayesinde hastaların hastanede geçirdikleri gün sayısında azalma ve maliyetlerinde düşme olduğu ifade edilmektedir (Kerkemeyer ve ark. 2018).

Yapılan literatür incelemesi sonucunda, ülkemizde ve dünyada şizofreni ve diğer psikotik bozukluklar da hemşireler tarafindan uygulanan psikososyal rehabilitasyon çalı̧̧malarının sınırlı sayıda olduğu saptanmıştır. Bu özden hareketle, bu derlemenin amacı, psikiyatri hemşireleri tarafından şizofreni tanılı hastalara uygulanan psikososyal rehabilitasyon programları ile ilgili çalışmaları gözden geçirmektir.

\section{Yöntem}

Araştırma süreci boyunca karşılaşılan nicel çalışmaların kombinasyonu nedeniyle araştırma deseninde raporlama özelliklerinin değerlendirilmesinde 27 maddeli PRISMA Bildirimi kullanıldı (Moher ve ark. 2009). 15-30 Mayıs 2019 tarihleri arasında Türk Psikiyatri Dizini [1] ve Pubmed [7] veri tabanları başlık ve özette "şizofreni”, "psikososyal rehabilitasyon” ve "hemşirelik", "schizophrenia", "psychosocial rehabilitation” ve "nursing" anahtar kelimeleri ile tarand.. Son arama 31 Mayıs 2019 tarihinde gerçekleştirildi.

Araştırma kapsamına 2008-2019 tarihleri arasında yayınlanan, tam metnine erişilen ve belirlenen anahtar kelimeleri karşılayan çalı̧̧malar alındı. Araştırmaya nicel desendeki tüm çalışmalar dahil edildi. Toplam 22 çalışmaya ulaşıldı ve bu çalışmalar arasından 8 makale değerlendirmeye alındı (Şekil 1). Derlemeye dahil edilen çalışmaların sayısının az olması çalışma sonuçlarının karşılaştırılmasında sınırlılığa neden olmuştur.

\section{Bulgular}

Yapılan sekiz çalışmanın 2011 ve 2019 yılları arasında; Güney Kore (2), Çin (1), Fransa (1), Kuzey Tayvan (1), Hollanda (1), İran (1) ve Türkiye'de (1) yapıldığı belirlendi. İncelemeye alınan çalışmaların çoğunluğunda örneklemi şizofreni tanılı hastalar oluşturduğu, Quee ve arkadaşlarının (2014) yaptığı çalışmada ise örneklemi şizofreni, şizoaffektif bozukluk ve psikotik bozukluğu olan hastaların oluşturduğu saptandı (Quee ve ark. 2014). Yapılan çalışmaların örneklem sayılarına bakıldığında, Ye ve ark.'nın (2017) şizofreni tanılı hastaların taburculuk devam eden hemşirelik bakımının hastaların rehabilitasyonu ve yaşam kalitesi üzerine etkilerini inceledikleri çalışmanın örneklem sayısı en fazla $(n=180)$ olduğu (Ye ve 


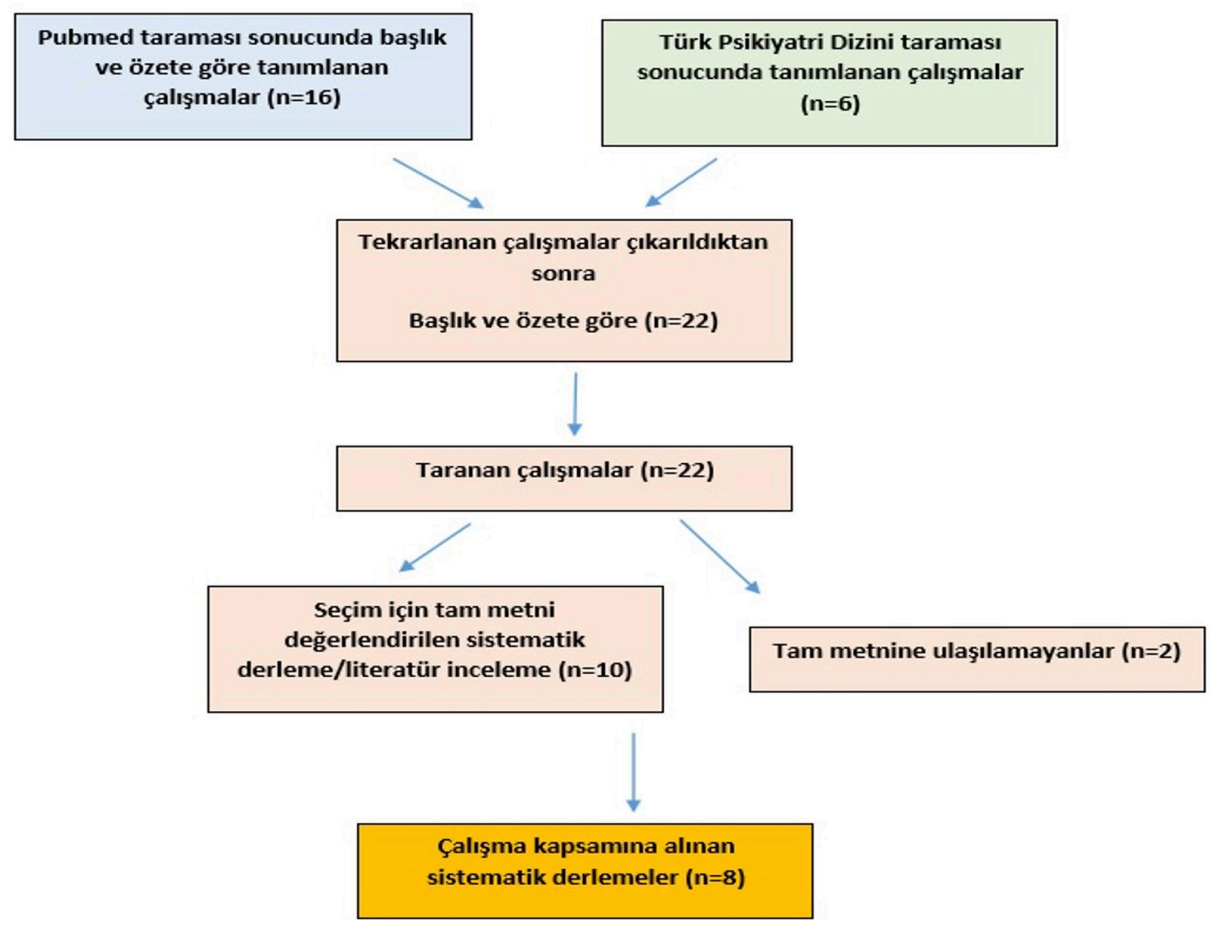

\section{Şekil 1. PRISMA akışş̧eması}

ark. 2017); Quee ve arkadaşlarının (2014) yaptığı, hemşirelik müdahalesi olarak bilişsel uyum eğitiminin etkinliğini ve uygulanabilirliğinin incelendiği araştırma ise örneklem sayısı en az ( $\mathrm{n}=30)$ olduğu çalışma olarak belirlendi (Quee ve ark. 2014).

Cho ve Jang'ın (2019) Güney Kore'de şizofreni tanılı hastalara uygulanan duygu yönetim programının etkisini incelendikleri yarı deneysel çalışmada; hastalar deney $(n=29)$ ve kontrol $(n=27)$ grubu olmak üzere iki gruba ayrılmıştır. Kontrol grubundaki hastalara, danışmanlık, psiko-eğitim, mesleki rehabilitasyon programı, terapötik aktiviteler (sanat terapisi, müzik terapisi, sosyal beceri eğitimi, meditasyon vb.) ve semptom yönetimini içeren rutin hemşirelik uygulamaları uygulanırken, deney grubundaki hastalara rutin hemşirelik uygulamalarına ilave olarak 8 hafta boyunca haftalık 50 dakikalık 8 oturum Yongin-Duygu Yönetim Eğitimi (Y-EMT) isimli duygu yönetim programı uygulanmıştır. Duygu Yönetim Programında oturumlar, 1sınma, programın uygulanması ve sonlandırma şeklinde üç bölüm içermektedir. Isınma olarak duygu tanıma ve ifadeyle ilgili basit oyunlar ve aktiviteler (alkışlama oyunu, bağırma oyunu, duygu sıfatlarıyla tombala yapma) gerçekleştirilmiştir. Oturumun ana bölümünde katılımcılar kısa bir bilgilendirme sonrası oturum konusunu tartışma veya yönetimi ile ilgili etkinliklere katılım sağlayıp (örneğin, belirli bir duyguyu ifade eden maskeler yapmak) sonunda ise düşüncelerini ve duygularını paylaşmı̧lardır. Çalışmada; duygu tanımayı, duygusal ifadeyi ve yaşam kalitesini değerlendirmek için ölçüm araçları kullanılmıştır. Çalışma sonucunda; duygu yönetim programına katılan deney grubundaki 
hastaların duygu tanıma (duygusal dikkat ve duygu netliği), duygusal ifade (olumlu ifade, olumsuz ifade ve dürtü gücü) ve yaşam kalitesi skorlarının anlamlı derecede arttığı, kontrol grubunda ise önemli ölçüde azaldığı tespit edilmiştir. Çalışma sonunda araştırmacılar, duygu yönetim programının şizofreni tanılı hastaların duygu tanıma, duygusal ifade ve yaşam kalitelerini artırmada yararlanacak bir program olabileceği, bu programın bu hastalar için etkili bir hemşirelik uygulaması olarak kullanılabileceği, tüm bunlar neticesinde sürekli duygusal uyarılmanın ve eğitimin hastaların yaşam kalitesini iyileştirmede etkili olduğunu vurgulamışlardır (Cho ve Jang 2019).

Ye ve arkadaşlarının (2017) Çin'de ayaktan takip edilen şizofreni tanılı hastaların gündüz rehabilitasyon programının yaşam kalitesi üzerindeki etkilerinin incelendiği çalışmada; hastalar deney $(n=90)$ ve kontrol $(n=90)$ grubu olmak üzere iki gruba ayrılmıştır. Deney grubundaki hastalara rutin taburculuk eğitimi ile hastane sonrasında daha sistematik devam eden kapsamlı hemşirelik bakım programı (yaşam tarzı, ilaç yönetimi, hemşirelik planı geliştirmek, taburcu edilecek şizofreni tanılı hastaları değerlendirmek ve değerlendirme sonuçlarına göre uygun bakım planını hazırlamak ve uygulamak, taburcu olduktan sonra ev ziyaretleri ve telefon takibi yapmak, posta yoluyla bilgilendirme ve WeChat çevirimiçi danışmanlık hizmeti) verilirken, kontrol grubuna ise sadece rutin taburculuk eğitimi verilmiştir. Çalışmada; hastalara psikiyatrik durum, rehabilitasyon durumu ve yaşam kalitesini değerlendirmek için ölçüm araçları kullanılmı̧ olup hastalar taburcu olduktan 6 ay sonra tekrar değerlendirilmiştir. Çalışma sonucunda; deney grubu için 6 ay sistematik olarak hastane dışında ayaktan devam eden kapsamlı hemşirelik bakımı sonrası tedaviye uyum, şizofreni ile ilgili bilgi düzeyinin kontrol grubuyla karşılaştırıldığında anlamlı derecede arttığı ve iki grup arasında anlamlı fark olduğu belirlenmiştir. Ayrıca deney grubundaki hastaların yaşam kalitesi puanlarının kontrol grubundaki hastalara oranla anlamlı derecede daha iyi olduğu bulunmuştur (Ye ve ark. 2017).

Gaudelus ve arkadaşlarının (2016) Fransa'da yaptıkları ve hastaların duygu tanıma süreçlerine odaklanan GAÏA s-yüz programı (GAÏA arm) ile seçici dikkate odaklanan ve nörobilişsel iyileştirme tedavisi olan RECOS programının (RECOS arm) etkinliğini karşılaştırdıkları çalışmada; bir gruba GAÏA yüz programı ( $n=18)$, diğer gruba ise RECOS programı ( $n=15)$ uygulanmıştır. GAÏA s-yüz programı; neşe, öfke ve üzüntüyü tanımak ve ayırt etmek için stratejiler geliştirmeyi amaçlayan fotoğraflarla bir egzersiz aşaması; beş farklı zorluk seviyesiyle dinamik durumlara uyarlamak için videoları kullanan bilgisayarlı bir egzersiz aşaması; diğer temel duyguları tanımak ve ayırt etmek (korku, iğrenme ve hor görmek) ile karmaşık duygular üzerinde çalışmaktan oluşan toplamda 3 aşamalı bir duygu tanıma programıdır. RECOS programı ise; nörobilişsel işlevlerden sözel bellek, çalışma belleği, yürütme işlevleri, bellek ve görsel-mekansal dikkat, seçici dikkat ve işlem hızının artırılması için geliştirilen bir programdır. RECOS programı; kâğıt ve kalem egzersizleri, bilgisayar egzersizleri ve terapist olmaksızın evde yapılan ev egzersizlerinden oluşmaktadır. Her iki program da haftada bir gün, bir saatlik, 3 seans yapılmaktadır. Her iki gruptaki hastalara 10 haftalık tedavi süresince 30 seans RECOS ve GAÏA s-yüz programları uygulanmış, hastalar 6 ay izlenmiştir. Çalışmada; hastaların duygularını tanıma, semptomlar, 
Tablo 1. Çalışmaya dahil edilen yayınların özellikleri ve yöntemleri

\begin{tabular}{|c|c|c|c|c|}
\hline Çalışma & $\begin{array}{l}\text { Çalışmanın } \\
\text { yapıldığıülke }\end{array}$ & $\begin{array}{l}\text { Çalışma } \\
\text { deseni }\end{array}$ & Amaç & Örneklem \\
\hline $\begin{array}{l}\text { Effect of an emotion } \\
\text { management programme for } \\
\text { patients with schizophrenia: } \\
\text { A quasi-experimental design }\end{array}$ & Güney Kore & Yarı deneysel & $\begin{array}{l}\text { Duygu yönetim programının } \\
\text { duyguları tanıma, duygusal } \\
\text { ifade ve yaşam kalitesi } \\
\text { üzerindeki etkisini incelemek }\end{array}$ & 56 hasta \\
\hline
\end{tabular}

(Cho ve Jang 2019).

\begin{tabular}{|c|c|c|c|c|}
\hline $\begin{array}{l}\text { Effects of out-of-hospital } \\
\text { continuing nursing on } \\
\text { schizophrenia patients' } \\
\text { rehabilitation and quality of } \\
\text { life (Ye ve ark. 2017). }\end{array}$ & Çin & RCT & $\begin{array}{l}\text { Hastane dışında devam eden } \\
\text { hemşirelik hizmetinin şizofreni } \\
\text { hastalarının rehabilitasyonu } \\
\text { ve yaşam kalitesi üzerindeki } \\
\text { etkilerini araşı̧ımak }\end{array}$ & 180 hasta \\
\hline
\end{tabular}

\begin{tabular}{|c|c|c|c|}
\hline $\begin{array}{l}\text { Improving facial emotion } \\
\text { recognition in schizophrenia: } \\
\text { A controlled study comparing } \\
\text { specific and attentional } \\
\text { focused cognitive remediation } \\
\text { (Gaudelus ve ark. 2016). }\end{array}$ & Fransa & $\mathrm{RCT}$ & $\begin{array}{l}\text { Yüzdeki duygu tanıma } \\
\text { süreçlerine odaklanan GAÏA } \\
\text { yüz programı ile seçici dikkate } \\
\text { odaklanan bir nörobilişsel } \\
\text { iyileştirme tedavisi olan RECOS } \\
\text { programını karşılaştırmak }\end{array}$ \\
\hline
\end{tabular}

\begin{tabular}{|c|c|c|c|c|}
\hline $\begin{array}{l}\text { The effects of auditory } \\
\text { hallucination symptom } \\
\text { management programme for } \\
\text { people with schizophrenia: } \\
\text { A quasi-experimental design } \\
\text { (Yang ve ark. 2015). }\end{array}$ & Kuzey Tayvan & Yarı deneysel & $\begin{array}{l}\text { Kronik şizofreni hastalarında } \\
\text { işitsel halüsinasyon semptom } \\
\text { yönetimi programının } \\
\text { etkinliğini ve anksiyete } \\
\text { belirtileri ile depresif belirtiler } \\
\text { düzeylerini karşlaştırmak }\end{array}$ & 58 hasta \\
\hline
\end{tabular}




\section{Uygulanan programlar Kullanılanölçümaraçları Sonuç}

*Yongin-Duygu Yönetim Eğitimi (Y-EMT)
* Travers Kısa Duygu Durumu

Ölçeği (Travers Meta Mood

Scale-short formu) (TMMSS)

* Berkeley Anlatım Anketi

(Berkeley Expressivity

Questionnaire)

* Nöroleptik Tedavide Subjektif

İyi OIma Ölçeği Kore Versiyonu

(Subjective Well-Being Under

Neuroleptic Treatment Scale)

* Hastane sonrasında daha sistematik devam eden kapsamlı hemşirelik bakım programı (yaşam tarzı, ilaç yönetimi, hemşirelik planı geliştirmek, taburcu edilecek şizofreni tanılı hastaları değerlendirmek ve değerlendirme sonuçlarına göre uygun bakım planını hazırlamak ve uygulamak, taburcu olduktan sonra ev ziyaretleri ve telefon takibi yapmak, posta yoluyla bilgilendirme ve WeChat çevirimiçi danışmanlık hizmeti vermek)

* GAÏA s-face programı (GAÏA arm) * RECOS programi (RECOS arm)
* Kısa Psikiyatrik Durum

Değerlendirme Ölçeği (BPRS)

* Morningside Rehabilitasyon Durum Değerlendirme Ölçeği

(Morningside Rehabilitation

Status Scale-MRSS)

* Genel Yaşam Kalitesi Envanteri (Generic Quality Of Life Inventory-GQOLI)
Bu çalışma bulguları, duygu yönetim programının şizofreni tanılı hastaların duygu tanıma, duygusal ifadesi ve yaşam kalitesi üzerindeki yararları için önemli ön kanıtlar sunmaktadır. Bu program, şizofreni tanılı hastalar için etkili bir hemşirelik müdahalesi olarak uygulanabilir. Ayrıca, bulgular sürekli duygusal uyarılmanın ve eğitimin şizofreni tanılı hastaların yaşam kalitesini iyileştirmede etkili olduğunu göstermektedir.

Bu çalışma bulguları, taburcu olduktan sonra şizofreni tanılı hastalar için hastane dışında devam eden hemşirelik hizmetinin, hastaların ilaç uyumunu, sağık bilgisi farkındalık oranını etkili bir şekilde iyileştirebileceği, şizofreni insidansını etkili bir şekilde azaltabileceği ve hastaların yaşam kalitesini arttıracağı ile ilgili kanıtlar sunmaktadır. Ayrıca bulgular, hemşirelik kavramını ve ilgili yöntemlerin tanıtımına, daha geniş bir alanda uygulanmasına katkı sağlayacağını göstermektedir.

\footnotetext{
* Yüz Duygularını Tanıma Görevi

(Facial Emotions Recognition

Task-TREF)

* Pozitif ve Negatif Belirtiler

Ölçeği (Positive and Negative

Syndrome Scale-PANSS)

* Sanrilar Envanteri (Delusions

Inventory-PDI21)

* Içgörü Ölçeği (Insight Scale-IS)

* Benlik Saygısı Değerlendirme

Ölçeği (Self-Esteem Rating

Scale-SERS)

* Sosyal Otonomi Ölçeği (Echelle

d'Autonomie Sociale-EAS)
}

Bu çalışma bulguları, her iki grupta da artmış yüz duygu tanıma performansı, azalmış semptomlar ve GAÏ̈A deney grubunda artmış sosyal işlevsellik ve her iki çalışma kolundaki bazı nörobilişsel ve sosyal bilişsel süreçlerin iyileştiğine dair kanıtlar sunmaktadır. Ek olarak, GAÏA programı tarafından geliştirilen bilişsel mekanizmaların anlayışı hala eksik olsa da, bu çalışmanın sonuçları, yüz duygu tanıma becerilerini geliştirmek, şizofrenide olumlu ve olumsuz belirtileri azaltmak ve sosyal işleyişi arttırmak için programın uygulanabilirliğini ve etkinliğini göstermiştir. Ayrıca, bu sonuçlar 3 günlük bir eğitim seansından sonra hemşireler tarafından sağlanan bilişsel iyileşmenin şizofreninin rutin bakımına potansiyel olarak dâhil edilerek ilaç tedavisi, psikoeğitim, sosyal beceri eğitimi ve psikoterapi ile birlikte yaygınlaşmasına katkı sağlayacağını göstermektedir.

Bu çalışma bulguları, deney grubunda zamanla kaygı semptomlarında anlamlı bir düzelme göstermezken, işitsel halüsinasyonlar anketi puanlarında müdahale sonrası 3 ve 6 aydaki kontrollerden daha fazla düşüş sağladığını ortaya koymuştur. Ek olarak, deney grubundaki Beck Depresyon Envanter II skorları da 3 ayda belirgin bir iyileşme göstermiştir. Ayrıca, işitsel halüsinasyon semptom yönetim programına katılımın düzenli ilaç tedavisi alan ancak işitsel halüsinasyonlardan muzdarip olan bireysel hastalar için etkili bir strateji olduğunu göstermektedir. 


\begin{tabular}{|c|c|c|c|c|}
\hline $\begin{array}{l}\text { Improving functional } \\
\text { outcomes for schizophrenia } \\
\text { patients in the Netherlands } \\
\text { using cognitive adaptation }\end{array}$ & Hollanda & $\mathrm{RCT}$ & $\begin{array}{l}\text { Bilişssel uyum eğitiminin bir } \\
\text { hemşirelik müdahalesi olarak } \\
\text { etkinliğini ve uygulanabilirliğini } \\
\text { araştırmak }\end{array}$ & 30 hasta \\
\hline
\end{tabular}

training as a nursing

intervention - A pilot study

(Quee ve ark. 2014).

\begin{tabular}{|c|c|c|c|c|}
\hline $\begin{array}{l}\text { Effect of the group music } \\
\text { therapy on brain wave, } \\
\text { behavior and cognitive } \\
\text { function among patients with } \\
\text { chronic schizophrenia (Kwon } \\
\text { ve ark. 2013). }\end{array}$ & Güney Kore & Yarı deneysel & $\begin{array}{l}\text { Kronik şizofreni hastalarında } \\
\text { grup müzik terapisinin beyin } \\
\text { dalgaları, davranı̧ ve bilişsel } \\
\text { işlev üzerindeki etkisini } \\
\text { incelemek }\end{array}$ & 55 hasta \\
\hline
\end{tabular}

\begin{tabular}{|c|c|c|c|}
\hline $\begin{array}{l}\text { The effects of nursing } \\
\text { discharge plan (post-discharge } \\
\text { education and follow-up) on } \\
\text { self-care ability in patients } \\
\text { with chronic schizophrenia } \\
\text { hospitalized in Razi psychiatric } \\
\text { center (Khankeh ve ark. 2011). }\end{array}$ & Yarı deneysel & $\begin{array}{l}\text { Kronik şizofreni hastalarının } \\
\text { taburculuk, eğitim ve takip } \\
\text { programının öz bakım } \\
\text { yetenekleri üzerindeki etkisini } \\
\text { belirlemek }\end{array}$ & 60 hasta \\
\hline
\end{tabular}

\begin{tabular}{|c|c|c|c|c|}
\hline $\begin{array}{l}\text { Bir Toplum Ruh Sağlığı } \\
\text { Merkezi'nde uygulanan } \\
\text { rehabilitasyon programlarına } \\
\text { katılan ve katılmayan } \\
\text { şizofreni hastalarının bazı } \\
\text { sosyodemografik ve hastalıkla } \\
\text { ilişkili özellikleri ile tedaviye } \\
\text { uyumları ve öz-yeterlilikleri } \\
\text { açısından tanımlanması } \\
\text { (Üstün ve ark. 2018). }\end{array}$ & Türkiye & Tanımlayıcı & $\begin{array}{l}\text { Bir Toplum Ruh Sağlığı Merkezi } \\
\text { (TRSM)'nde uygulanan } \\
\text { rehabilitasyon programlarına } \\
\text { katılan ve katılmayan } \\
\text { şizofreni hastalarının bazı } \\
\text { sosyodemografik ve hastalıkla } \\
\text { ilişskili özellikleri ile tedaviye } \\
\text { uyumları ve öz yeterliliklerini } \\
\text { tanımlamak }\end{array}$ & 64 hasta \\
\hline
\end{tabular}

düşünce süreçleri, içgörürü, benlik saygısı ve sosyal işlevsellik durumlarını değerlendirmek için ölçüm araçları kullanılmıştır. Başlangıçta, tedavi sonrası 11. haftada ve 6. ayda olmak üzere ölçümler yapılmıştır. Çalışma sonucunda; her iki grupta da artmış yüz duygu tanıma performansı, azalmış semptomlar, nörobilişsel ve sosyal bilişsel süreçlerinde kısmi iyileşme; GAÏA uygulanan grupta ise artmı̧̧ sosyal işlevsellik saptanmıştır (Gaudelus ve ark. 2016).

Yang ve arkadaşlarının (2015) Kuzey Tayvan'da yaptıkları çalışmada; düzenli ilaç tedavisi alan ancak işitsel halüsinasyonları olan hastalarda İşitsel Halüsinasyon Semptom Yönetimi Programının etkinliği incelenmiştir. Hastalar deney ( $n=29)$ ve kontrol ( $n=29)$ grubu olarak iki gruba ayrılmıştır. Deney grubundaki hastalara İşitsel Halüsinasyon Semptom Yönetimi 
* Bilişsel uyum eğitimi (Cognitive Adaptation Training-(AT)
* Pozitif ve Negatif Belirtiler Ölçeği (Positive and Negative Syndrome Scale)

* Multnomah Toplum Yetenek Ölçeği (Multnomah Community Ability Scale-MCAS)

* Sosyal ve Mesleki İşlevsellik Ölçeği (Social and Occupational Func tioning Scale-SOFAS)

* Negatif Belirtileri Değerlendirme ÖlçeğiMotivasyon alt ölçeği (Negative Symptom Assessment-NSA-M)

* Grup müzik terapisi

* Elektroensefalografi (EEG)
* Mini Mental Durum Testi (Mini-Mental State Examination-MMSE)

* Hemşirelerin Yatan Hasta Değerlendirme Gözlem Ölçeği (Nurses' Observation Scale for Inpatient Evaluation-NOSIE)

* Hastalara: Öz bakım, tedavinin sürekliliği ve ilaçların önemi, fiziksel, zihinsel ve sosyal sağlığı iyileştirme ve sürdürme yolları, stres ile başetme yöntemleri

* Ailelere: Kriz durumlarına nasıl müdahale edileceği ve hastalık belirtileri ile nasıl başa çıkılacağı

* Evde bakım hizmeti

${ }^{*}$ Anket Formu
Bu çalışma bulguları, deney grubundaki hastaların, Multnomah toplum yeteneği ölçeğinde kontrol grubu hastalarına göre daha iyi skorlara sahip olduğunu ortaya koymuştur. Ek olarak, deney grubu yatan hastalarının işle ilgili faaliyetleri kontrol grubu yatanlarına göre arttığı ve 10 ay sonra önem kazandığı ortaya koyulmuştur. Ayrıca, bir hemşirelik müdahalesi olarak bilişsel uyum eğitiminin, uzun süre hastanede yatan hastalar da dâhil olmak üzere, Hollanda'da yaşayan şizofreni tanılı hastalarda olumlu etkilere sahip olduğunu göstermektedir.

Bu çalışma bulguları, grup müzik terapisi ile kronik şizofreni tanılı hastalarda duygusal gevşeme, bilişsel işleme yeteneklerinin yanı sıra olumlu davranış değişikliklerinin geliştirilmesine yönelik etkili bir müdahale olduğunu ortaya koymuştur. Ayrıca sonuçlar kronik psikiyatri hastalarından muzdarip olanlar için psikiyatrik rehabilitasyona yönelik müdahale stratejileri oluşturmada yararlı olabileceğini göstermektedir.

* Demografik Veri Anketi Bu çalışma bulguları, müdahale sonrası öz bakım becerileri arasında deney grubunun (1 aydan 6 aya kadar) kontrol grubuna kıyasla anlamlı bir fark olduğu ortaya koymuştur. Ayrıca sonuçlar evde bakım hizmetinin kronik psikiyatrik bozukluğu olan hastaların kendi kendine bakım yeteneği ve bağımsızlığı üzerine fayda sağladığını göstermektedir.
* Haftalık: Her sabah ısınma egzersizi, günaydın toplantıları, resim ve iş-uğraşı terapisi, müzik terapisi, tiyatro gibi sanatsal etkinlikler ile dönüşümlü olarak film gösterimi, kitap okuma aktiviteleri

* Haftada bir gün: Sosyal beceri eğitimleri ve danışan psikoeğitimleri

${ }^{*}$ Ayda bir kez: Aile psikoeğitim grubu
* Kişisel bilgi formu

* Morisky Uyum Ölçeği (MUÖ)

* Öz Etkililik-Yeterlilik Ölçeği

(ÖYÖ)
Bu çalışma bulguları, rehabilitasyon programına katılan şizofreni tanılı hastaların tedaviye uyumlarının, rehabilitasyon programlarına katılmayanlara göre daha yüksek olduğunu ortaya koymuştur.

(Auditory Hallucinatory Symptom Management-AHSM) programı uygulanmıştır. İşitsel Halüsinasyon Semptom Yönetimi Programı (İHSYP), haftada bir kez 60 dakika olarak toplamda 10 hafta 10 oturum şeklinde uygulanmıştır. İHSYP'ninde hastalara akşam yemeğinden sonra 1 saat boyunca görüşmeler yapılarak, grup üyeleri işitsel halüsinasyon deneyimlerini paylaşmaları konusunda teşvik edilmiş, gruba işitsel halüsinasyonlarla baş etme stratejileri öğretmenin yanı sıra üyelere bu stratejileri uygulama firsatları da sağlanmıştır. On haftalık İHSYP; kendini izleme, başka şeyler yaparak kendini seslerden uzaklaştırma, biriyle konuşma, okuma, müzik dinleme, televizyon izleme, kulak tıkacı kullanma veya birinin kulaklarını kapatmasını isteme, derin nefes alma, kasları gevşetme veya gevşetici 
müzik dinleme gibi halüsinasyonlarla baş etme stratejileri içermektedir. Kontrol grubundaki hastalara ise 10 hafta boyunca rutin hemşirelik bakımı uygulanmıştır. Çalışmada; depresyon, anksiyete ve işitsel halüsinasyonları değerlendirmek için ölçüm araçları kullanılmıştır. Veriler, uygulamanın hemen sonrası ve uygulamadan 3 ve 6 ay sonra olmak üzere toplamda üç kez toplanmıştır. Çalışma sonucunda; deney grubundaki hastaların zamanla anksiyetelerinde anlamlı bir azalma saptanmazken, işitsel halüsinasyonlarında müdahale sonrası, 3. ve 6. ayda, depresif belirtilerinde ise 3. ayda kontrol grubundaki hastalara oranla azalma saptanmıştır (Yang ve ark. 2015).

Quee ve arkadaşlarının (2014) Hollanda'da hastaların bilişsel yeteneklerini geliştirmeyi amaçlayan psikososyal bir müdahale olan Bilişsel Uyum Eğitimi'nin (Cognitive Adaptation Training-CAT) etkinliğini ve uygulanabilirliğini inceledikleri çalı̧̧mada; hastalar deney ( $n=16)$ (10'u yatan hasta) ve kontrol ( $n=14)$ (9'u yatan hasta) grubu olmak üzere iki gruba ayrılmıştır. Deney grubundaki hastalara rutin tedavinin yanında ev ziyaretlerinde, 8 ay boyunca haftalık ortalama (yatan hastalarda günlük ve haftalık, ayaktan hastalarda ise iki haftada bir) 45 dakikalık Bilişsel Uyum Eğitimi (bireysel tedavi planları, bireysel davranışsal ve bilişsel destek eğitimi, çevresel destek) verilirken, kontrol grubundaki hastalara ise sadece rutin tedavileri (farmakoterapi, psikoeğitim, bilişsel davranış̧̧ı terapi, psikomotor terapi, yaratıcı sanatlar terapisi, eğitici projeler, çeşitli spor grupları, akran destek grupları) uygulanmıştır. Çalışmada; semptomları, toplum yeteneğini, sosyal ve mesleki işlevselliği değerlendirmek için ölçüm araçları kullanılmıştır. Veriler; başlangıçta, uygulamadan 4 ve 8 ay sonra olmak üzere toplamda üç kez toplanmıştır. Yatan hastalar için ise başlangıçtan sonraki 16 ay boyunca izlenmiştir. Çalışma sonucunda; deney grubundaki hastaların, toplum yetenek ölçeği toplam puan ortalamalarının arttığ1 ve kontrol grubundaki hastalarla aralarında anlamlı fark olduğu belirlenmiştir. Buna ek olarak, deney grubu yatan hastalarının işle ilgili faaliyetleri kontrol grubu yatanlarına göre arttığı belirlenmiştir (Quee ve ark. 2014).

Kwon ve arkadaşlarının (2013) Güney Kore'de kronik şizofreni tanılı hastalarda grup müzik terapisinin beyin dalgaları, davranı̧̧ ve bilişsel işlevleri üzerindeki etkisini incelemek amacıyla yarı deneysel olarak yaptıkları çalışmada; hastalar deney $(n=28)$ ve kontrol $(n=27)$ grubu olmak üzere iki gruba ayrılmıştır. Deney grubundaki hastalar, standart tedavilerine ek olarak 7 hafta boyunca haftada 2 kez 50 dakikalık (1sınma $10 \mathrm{dk}$, uygulama $30 \mathrm{dk}$, kapanış $10 \mathrm{dk}$ ) toplamda 13 seans grup müzik terapisine katılmışlardır. Müzik terapisi oturumları, profesyonel bir müzik terapisti ve iki psikiyatri hemşiresi tarafından yönetilmiştir. Grup müzik terapisinin içeriği; şarkı söyleme, çalma ve dinleme şeklindedir. Hastaların müzik tercihi dikkate alınarak şarkı ve müzik aletleri seçilmiştir. Terapi ayrıca bilişsel stimülasyon eğitimi, etkileşim ve müzik aktiviteleri yoluyla fiziksel aktivite kombinasyonunu içermektedir. Kontrol grubundaki hastalar ise sadece rutin olarak sağlanan farmakolojik tedavilerini ve hemşirelik bakımı almıştır. Çalışmada; beyin dalgaları, bilişsel işlev, hastaların davranı̧̧larını değerlendirmek için ölçüm araçları kullanılmıştır. Veriler; ön test-son test şeklinde toplamda iki kez toplanmıştır. Çalışma sonucunda; grup müzik terapisi ile deney grubundaki kronik şizofreni tanılı hastalarda dikkat, hesaplama, dil gelişiminin yanı sıra, duygusal rahatlama, bilişsel becerilerinin geliştiği belirlenmiştir (Kwon ve ark. 2013). 
Khankeh ve arkadaşlarının (2011) İran'da kronik şizofreni tanılı hastaların taburculuk, eğitim ve takip programının öz bakım becerileri üzerindeki etkisini belirlemek amacıyla yarı deneysel olarak yaptıkları çalışmada; deney $(n=30)$ ve kontrol $(n=30)$ olmak üzere hastalar iki gruba ayrılmıştır. Deney grubundaki hastalara taburcu olduktan sonra 6 ay boyunca öz bakım, tedavinin sürekliliği ve ilaçların önemi, fiziksel, zihinsel ve sosyal sağlığı iyileştirme ve sürdürme yolları, stres ile baş etme yöntemleri; ailelerine ise, kriz durumlarına nasıl müdahale edileceği ve hastalık belirtileri ile nasıl başa çıkılacağını içeren eğitim programı ve evde bakım hizmeti; kontrol grubundaki hastalara ise rutin taburculuk eğitimi verilmiştir. Çalışmada; sosyodemografik veriler ve öz bakım becerilerinin değerlendirilmesinde araştırmacılar tarafından hazırlanan form kullanılmıştır. Veriler; eğitimden 1 ay önce ve taburcu olduktan 6 ay sonra toplanmıştır. Çalışma sonunda; uygulama sonrası deney grubundaki hastaların öz bakım becerilerinin kontrol grubundaki hastalara göre anlamlı olarak yükseldiği belirlenmiştir. Araştırmacılar evde bakım hizmetinin kronik psikiyatrik bozukluğu olan hastaların öz bakım becerileri ve bağımsızlık düzeyleri üzerine olumlu etki yarattığını vurgulamışlardır (Khankeh ve ark. 2011).

Üstün ve arkadaşlarının (2018) ülkemizde Toplum Ruh Sağlığı Merkezi’nde (TRSM) uygulanan rehabilitasyon programlarına katılan ve katılmayan şizofreni tanılı hastaların bazı tedaviye uyum ve öz yeterliliklerini karşılaştırmak amacıyla yaptıkları tanımlayıcı tipteki çalışmada; rehabilitasyon programlarına düzenli (haftada en az bir gün) katılan ( $n=32$ ) ve rehabilitasyon programlarına katılmayan $(n=32)$ hastalar ile çalışılmıştır. Merkezin haftalık programı içerisinde her sabah 1sınma egzersizi, günaydın toplantıları, resim ve iş-uğraşı terapisi, müzik terapisi, tiyatro gibi sanatsal etkinlikler sürdürülmekte, film gösterimi, kitap okuma gibi aktiviteler dönüşümlü olarak devam etmekte, haftada 1 gün sosyal beceri eğitimleri ve danışan psikoeğitimleri, ayda $1 \mathrm{kez}$ ise aile psikoeğitim grubu yürütülmektedir. Çalışmada; hastaların uyumları ve öz etkililik-yeterliliklerini değerlendirmek için ölçüm araçları kullanılmıştır. Hastalarla görüşmeler çalışmanın yapıldığ 3 aylık süre içerisinde TRSM'ye düzenli gelenlerle merkezde, gelmeyenlerle ise telefonla yapılmıştır. Çalışma sonucunda; rehabilitasyon programına katılan deney grubundaki şizofreni tanılı hastaların tedaviye uyumlarının, rehabilitasyon programlarına katılmayan kontrol grubundaki hastalara göre daha yüksek olduğu bulunmuştur. İki grup arasında öz yeterlilik ölçek puanları açısından anlamlı bir fark bulunmamıştır (Üstün ve ark. 2018).

\section{Tartışma}

Şizofreni, duygusal sorunları içeren, affektif bozukluklar ile sosyal işlevselliği bozan bir hastalıktır. Şizofreni tanılı bireyler, duygularını anlama, yönetme ve empatik yeteneklerini geliştirme konularında zorluk yaşamaktadır (Cho ve Jang 2019). Bu nedenle, şizofreni tanılı hastalar arasında duygusal ifadenin geliştirilmesine yardımcı olacak psikososyal rehabilitasyon müdahaleleri kullanılmaktadır. Cho ve Jang'ın (2019) yaptığı çalışmada; deney grubunda yer alan hastaların duygusal ifadelerinin kontrol grubuna kıyasla daha fazla geliştiği bulunmuştur. Gaudelus ve arkadaşları (2016) tarafından yapılan bir diğer çalışmada da; duyguları tanıma süreçlerine ve nörobilişsel iyileştirmeye odaklanan programlar sayesinde 
hastaların yüz duygu tanıma becerilerinin geliştiği, negatif ve pozitif belirtilerin azaldığı ve sosyal işlevselliklerinin geliştiği bulunmuştur. Yapılan bir başka çalışma da şizofrenide anhedoni ve ilgisizliği azaltmak amacıyla hemşireler tarafindan 8 oturumluk şizofreni için pozitif duygular programı uygulanmış ve programa katılan hastaların anhedonia ve ilgisizliğinde belirgin bir şekilde azalma olmasının yanı sıra söz konusu programın hemşireler tarafından uygulanabilir bir müdahale olduğu görülmüştür (Favrod ve ark. 2015). $\mathrm{Bu}$ çalışmaların bulgularına göre; psikososyal rehabilitasyon hizmetlerinde şizofreni tanılı hastaların duygu tanıma ve gelişimine yönelik geliştirilen eğitim ve bilişim teknolojileri uygulamalarının hastaların çeşitli duyguları tanıma, duygusal yüz ifadelerini ve duygusal kelimelerin kullanımını tekrarlama ve duyguları çeşitli kelimelerle ifade etmelerine katkı sağlayacağı, tüm bunlar sonucunda da bireylerin kişilerarası ilişkileri, sosyal davranışları ve yaşam kalitesinin gelişeceği söylenebilir. Sonuç olarak, bu ve benzer programlar şizofreni tanılı hastaların rehabilitasyonunda yararlı birer psikiyatri hemşireliği uygulama programlarından biri olabilir.

Birçok şizofreni tanılı hastanın hastanede yatı̧̧ı sırasında tedavi ve ilaç uyumunu sağladığı, ancak hastaların taburcu olduktan sonra istemli olarak ilaç kullanımını bıraktığı ya da ilaç uyumsuzluğu olduğu bilinmektedir (Ye ve ark. 2017). Ye ve arkadaşlarının (2017) yaptıkları çalışmada; deney grubu için 6 aylık ayaktan devam eden kapsamlı hemşirelik bakımı sonrası tam tedaviye uyum oranı, şizofreni ile ilgili sağlık bilgisi farkındalık oranının kontrol grubuyla karşılaştırıldığında anlamlı derecede arttığ bulunmuştur. Yapılan bir başka çalışmada psikiyatri hemşireleri tarafından uygulanan psikoeğitim programının hastanede yatan şizofreni hastalarının ilaç uyumunu artırmada etkili olduğu, ilaçla normal bir yaşam sürdürme yeteneği sağladığı ve hastaların ilaç uyumunu geliştirmeye katkıda bulunduğu görülmüştür (Matsuda ve ark. 2016). Bu çalışmalar sonucuna göre; hastaların taburcu olduktan sonra tedaviye uyumunun yüksek olmasını sağlamak için daha sistematik, kapsamlı ayaktan psikososyal rehabilitasyon programlarına ihtiyaç vardır. Aksi takdirde hastaların tekrarlı yatışlarına yol açan döner kapı fenomeni devam edebilir.

Şizofreni tanılı hastalarda düzenli ilaç kullanımı, hastaların \%50-60'ının belirtilerini azaltmakta, ancak bazı hastaların inatçı belirtileri devam etmektedir. İşitsel halüsinasyonlar hastaları rahatsız eden halüsinasyonlar arasındadır. İşitsel halüsinasyonlar agresif hareketler, intihar davranışı ve düşüncesi, sosyal geri çekilme ve etkileşimin bozulması gibi diğer belirtilere neden olmaktadır (Yang ve ark. 2015). Bu nedenle, tedaviye uyumu iyi olup inatçı belirtilerden rahatsiz olan hastalarda bu belirtilerin olumsuz etkilerini azaltmak amaciyla psikososyal rehabilitasyona yönelik stratejiler geliştirilmelidir. Yang ve arkadaşlarının (2015) yaptıkları çalışmada; İşitsel Halüsinasyon Semptom Yönetimi Programı alan deney grubundaki hastaların işitsel halüsinasyonların rahatsız edici etkilerinin kontrol grubundaki hastalara oranla anlamlı şekilde azaldığı bulunmuştur. Tayland'da şizofreni tanısı ile takip edilen hastalara psikiyatri hemşireleri tarafindan uygulanan semptom yönetim programının işitsel halüsinasyonlar üzerindeki etkilerinin incelendiği bir çalı̧̧mada; 10 oturumluk bir semptom yönetim programı uygulanan olguların işitsel halüsinasyon puanlarında önemli ölçüde azalma olduğu görülmüştür (Kanungpairn ve ark. 2007). Bu sonuçlara göre; 
psikiyatri hemşireleri tarafından psikososyal rehabilitasyon müdahalesi olarak uygulanacak semptom yönetimi programlarının inatçı belirtileri olan hastalar için etkili bir strateji olacağı söylenebilir.

Şizofreni tanılı hastalarda bilişsel alanların çoğunda bozulmalar görülmektedir. Bu bilişsel açıklar, uzun vadeli işlevsellikte bozulmaya neden olmaktadır. Bilişsel bozulmaya yönelik tedaviler giderek daha fazla dikkat çekmektedir. Farmakolojik tedavilerin pozitif semptomları azaltmada başarılı olduğu kanıtlanmış olsa da antipsikotik tedaviyi takiben bilişsel gelişmelerin sınırlı olduğu bulunmuştur (Quee ve ark. 2014). Bu nedenle, psikososyal rehabilitasyon kapsamındaki bilişsel uyum tedavileri hastaların yaşam alanında çevresel desteklerin kullanımı ile işlevselliği geliştirmede etkilidir. Quee ve arkadaşlarının (2014) yaptıkları çalışmada; bilişsel uyum eğitiminin etkinliği ve uygulanabilirliği deney grubunda kontrol grubuna kıyasla yüksek bulunmuştur. Bu çalı̧̧mayı destekleyen nitelikte, şizofreni gibi uzun süreli yoğun psikiyatri hizmetlerine ihtiyacı olan kişilere hemşireler tarafindan verilen bilişsel uyum eğitiminin günlük işleyişe etkilerinin incelendiği bir çalışmada; bilişsel uyum eğitimi uygulanan olguların 12 ay sonra günlük işlevsellik, yürütücü işlevler ve görsel dikkat konusunda önemli ölçüde iyileşme gösterdiği ve bu durumu sürdürdüğü görülmüştür (Stiekema ve ark. 2020). Bu sonuçlar değerlendirildiğinde; ruhsal bozukluğu olan bireylerle sürekli temas halinde olup daha uzun süre vakit geçiren ve terapötik ilişki içinde bulunan psikiyatri hemşirelerinin bilişsel uyum eğitiminde aktif rol alabilecekleri ve günlük çalışma rutinlerinde uygulayabilecekleri söylenebilir.

Müzik terapisi, şizofrenide psikiyatrik semptomları ve gerilemeyi yönetmenin yanı sıra gelişmiş sosyal etkileşim ve nörofizyolojik fonksiyona neden olan psikososyal müdahalelerden biridir. Müzik terapisi ayrıca sinir sistemi, endokrin sistem ve kardiyovasküler sistem içindeki fizyolojik tepkileri ve aktiviteleri de etkileyerek zihinsel ve bedensel stabilizasyona, gelişmiş duygu, bilişsel işlev ve olumlu davranışlara yol açmaktadır (Kwon ve ark. 2013). Kwon ve arkadaşlarının (2013) yaptıkları çalı̧̧mada; kullanılan grup müzik terapisi ile kronik şizofreni tanılı hastalarda dikkat, hesaplama, dil gelişiminin yanı sıra, duygusal rahatlama, bilişsel işleme becerilerinin geliştiği bulunmuştur. Müzik müdahalesinin şizofrenide beynin fonksiyonel bağlantı gücü üzerine etkilerinin incelendiği bir başka çalışmada; 1 ay boyunca müzik müdahalesi uygulanan olguların fonksiyonel manyetik rezonans görüntüleme yöntemi ile incelemeleri sonucunda müzik müdahalesinin beynin fonksiyonel bağlantısında olumlu yönde değişiklikler yaptığı görülmüştür (Yang ve ark. 2018). Elde edilen bu sonuçlara göre; ruhsal bozukluğu olan hastalarda psikiyatrik rehabilitasyon müdahaleleri içinde müzik terapinin uygulanabileceği söylenebilir.

Kronik şizofreni tanılı hastaların hastaneden taburculuğuyla başlayan ve toplumda devam eden evde bakım ihtiyacının artması ile son yıllarda ruhsal bozukluğu olan hastaların bakımında değişikliğe sebep olmuştur. Evde bakım hizmetinin kronik ruhsal bozukluğu olan hastaların kendi kendine bakım kabiliyeti ve bağımsızlığı üzerine fayda sağladığ1 bilinmektedir (Khankeh ve ark. 2011). Khankeh ve arkadaşlarının (2011) yaptığı çalışmada; ev ziyaretleri uygulaması sonrası deney ve kontrol grubundaki hastaların öz bakım becerileri arasında anlamlı fark saptanmıştır. Tayvan'da taburcu olan şizofreni hastalarına uygulanan 
hastalık yönetimi ve iyileşme programının etkilerinin incelendiği bir başka çalışmada; programın tamamlanmasından sonra hastalarda tedaviyle ilişkili hastalık bilgisi, içgörü, ilaçlara karşı tutum ve duyuşsal alan psikopatolojisi yönünden iyileşme olduğu görülmüştür (Lin ve ark. 2013). Bu çalışmaların sonucuna göre; hastaların taburculuk sonrası izlem ve ev ziyaretlerinin hastane ile toplum arasında güçlü bağlantılar kurulması ile hastaların iyileşmeleri, sağlık harcamalarının ve sosyal maliyetlerinin azalması açısından yararlı olabileceği söylenebilir. Ayrıca; Üstün ve arkadaşları (2018) tarafından TRSM'de uygulanan rehabilitasyon programlarına katılan şizofreni tanılı hastaların tedaviye uyumlarının, katılmayan hastalara göre daha yüksek olduğu bulunmuştur. Bu çalı̧̧ma sonucuna göre; şizofreni tanılı hastaların öz yeterlilikleri ile ilaç uyumlarının artırılması amacıyla rehabilitasyon programlarına katılması konusunda desteklenmeleri gerektiği söylenebilir.

\section{Sonuç}

$\mathrm{Bu}$ sistematik derleme sonucunda psikiyatri hemşireleri tarafindan şizofreni tanılı hastalara uygulanan psikososyal rehabilitasyon programlarının sınırlı sayıda olduğu, psikiyatri hemşirelerine yönelik bu alanda eğitim, uygulama ve araştırmalara ihtiyaç olduğu saptanmıştır. Değerlendirmeye alınan tüm çalı̧̧malarda psikiyatri hemşireleri tarafindan şizofreni tanılı hastalara uygulanan psikososyal rehabilitasyon programlarının olumlu sonuçları olduğu görülmektedir. Derleme kapsamına alınan psikososyal rehabilitasyon programlarının içeriği incelendiğinde program içeriklerinin şizof reni tanılı hastaların baş etme düzeyleri ile öz bakım yeteneklerini geliştirme; sosyal-bilişsel işlevselliğini sağlama, tedaviye uyumlarını ve yaşam kalitelerini arttırma, hastanede yatı̧s süresinde ve nükslerde azalma, işitsel halüsinasyonlarla baş edebilme ve duygu tanımalarında iyileşme sağladığı belirlendi. Şizofreni tanılı hastalara uygulanan psikososyal rehabilitasyon programlarının yaygınlaştırılması ve ruh sağlığı sistemi içinde yer alması gerekmektedir. Ülkemizde şizofreni tanılı hastalara yönelik psikososyal rehabilitasyon programları sistematik ve planlı bir şekilde uygulanamamaktadır. Ülkemizde ruhsal bozukluğu olan hastalarda yeti yitiminin azaltılması, ruhsal, toplumsal ve mesleki işlevselliğinin arttırılmasına katkı sağlayan psikososyal rehabilitasyon programlarının geliştirilmesi ve yaygınlaştırılması gereklidir. İncelenen uluslararası sistematik derlemelerde olduğu gibi ülkemizde de psikososyal rehabilitasyon programlarının uygulanması ve sürdürülmesinde uzman psikiyatri hemşireleri aktif rol alabilirler. Psikiyatri hemşireleri şizofreni tanılı hastaların sağllğıını korumak ve geliştirmek için psikososyal rehabilitasyon programlarını planlama, uygulama, değerlendirme ve izleme alanlarında yer almalıdır. Ayrıca psikiyatri hemşireleri vaka yöneticisi rolü çerçevesinde bilgi ve becerileriyle hastanın gereksinimleri doğrultusunda psikososyal rehabilitasyon programlarına dahil edilmesi, izlenmesi ve sonuçlarının paylaşılması aşamalarında aktif rol almalıdır.

\section{Kaynaklar}

Akpınar Ş, Kelleci M (2008) Şizofrenik hastalara uygulanan sorun çözme becerilerin geliştirme programının yaşam kalitesine etkisi. Klinik Psikiyatri Dergisi, 11:180-190.

Arslan M, Yazıcı A, Yılmaz T, Coşkun S, Kurt E (2015) Rehabilitasyon programının şizofreni hastalarının kliniği, sosyal işlevselliği ve yaşam kalitesi üzerindeki uzun dönem etkileri: İzleme çalışması. Anadolu Psikiyatri Derg, 16:238-246. 
Cho M, Jang SJ (2019) Effect of an emotion management programme for patients with schizophrenia: A quasi-experimental design. Int J Ment Health Nurs, 28:592-604.

Çetinkaya Duman Z, Aştı N, Üçok A, Kuşcu MK (2007) Şizofreni hastalarına ve ailelerine bağımsız ve sosyal yaşam becerileri topluma yeniden katılım programı uygulaması, izlenmesi. Anadolu Psikiyatri Derg, 8:91-99.

Doğan S, Doğan 0, Tel H, Çoker F, Polatöz Ö, Başeğmez FD (2002) Şizofrenide psikososyal yaklaşımlar: Ayaktan hastalar. Anadolu Psikiyatri Derg, 3:69-74.

Favrod J, Nguyen A, Fankhauser C, Ismailaj A, Hasler JD, Ringuet A et al. (2015) Positive Emotions Program for Schizophrenia (PEPS): A pilot intervention to reduce anhedonia and apathy. BMC Psychiatry, 15:231.

Gaudelus B, Virgile J, Geliot S, The GAÏA/RECOS Study Team, Franck N (2016) Improving facial emotion recognition in schizophrenia: A controlled study comparing specific and attentional focused cognitive remediation. Front Psychiatry, 7:105.

Hogarty GE, Flesher S, Ulrich R (2004) Şizofreni için bilişsel pekiştirme terapisi: Biliş ve davranış üzerine 2 yıllık randomize bir çalışmanın etkileri. Arch Gen Psychiatry, 61:866-876.

Hutchison SL, MacDonald-Wilson KL, Karpov I, Maise AM, Wasilchak D, Schuster JM (2017) Value of psychiatric rehabilitation in a behavioral health medicaid managed care system. Psychiatr Rehabil J, 40:216-224.

Kanungpairn T, Sitthimongkol Y, Wattanapailin A, Klainin P (2007) Effects of a symptom management program on auditory hallucinations in Thai outpatients with a diagnosis of schizophrenia: A pilot study. Nurs Health Sci, 9:34-39.

Kerkemeyer L, Wasem J, Neumann A, Brannath W, Mester B, Timm J, et al. (2018) Effectiveness and cost-efectiveness of an integrated care program for schizophrenia: An analysis of routine data. Eur Arch Psychiatry Clin Neurosci, 268611-619.

Khankeh H, Rahgozar M, Ranjbar M (2011) The effects of nursing discharge plan (post-discharge education and follow-up) on selfcare ability in patients with chronic schizophrenia hospitalized in Razi psychiatric center. Iran J Nurs Midwifery Res, 16:162-168.

Kopelowicz A, Zarate R, Wallace CJ, Liberman RP, Lopez SR, Mintz J (2012) The ability of multifamily groups to improve treatment adherence in Mexican Americans with schizophrenia. Arch Gen Psychiatry, 69:265-273.

Kwon M, Gang M, Oh K (2013) Effect of the group music therapy on brain wave, behavior, and cognitive function among patients with chronic schizophrenia. Asian Nurs Res, 7:168-174.

Lin E C-L, Shao WC, Chan ÇH, Shiau S, Wang H-S, Huang S-C (2013) A pilot study of an illness management and recovery program in discharged patients with schizophrenia. J Nurs Res, 21:270-277.

Matsuda M, Ayumi Kohno A (2016) Effects of the nursing psychoeducation program on the acceptance of medication and conditionspecific knowledge of patients with schizophrenia. Arch Psychiatr Nurs, 30:581-586.

Mitra S, Natarajan R, Ziedonis D, Fan X (2017) Antioxidant and anti-inflammatory nutrient status, supplementation, and mechanisms in patients with schizophrenia. Prog Neuropsychopharmacol Biol Psychiatry, 78:1-11.

Moher D, Liberati A, Tetzlaff J, Altman DG, PRISMA Group (2009) Preferred reporting items for systematic reviews and meta-analyses: The PRISMA Statement. PLOS Med, 151:264-269.

Morin L, Franck N (2017) Rehabilitation interventions to promote recovery from schizophrenia: A systematic review. Front Pychiatry, $8: 100$.

Os J, Kapur S (2009) Schizophrenia. Lancet, 374:635-645.

Özdemir İ, Şafak Y, Örsel S, Karaoğlan Kahiloğulları A, Karadağ H (2017) Bir Toplum Ruh Sağlığı Merkezinde şizofreni hastalarına uygulanan ruhsal-toplumsal uyumlandırma etkinliğinin araştıııması: Kontrollü çalışma. Anadolu Psikiyatri Derg, 18:419-427.

Quee PJ, Stiekema AP, Wigman JT, Schneider H, Meer L der van, Maples NJ et al. (2014) Improving functional outcomes for schizophrenia patients in the Netherlands using Cognitive Adaptation Training as a nursing intervention-A pilot study. Schizophr Res, 158:120-125.

Stiekema A PM, T van Barajı M, Bruggeman R, Redmeijer JE, Swart M, Dethmers M, et al. (2020) Facilitating recovery of daily functioning in people with a severe mental Illness who need longer-term intensive psychiatric services: results from a cluster randomized controlled trial on cognitive adaptation training delivered by nurses. Schizophr Bull, 46:1259-1268.

Üstün G, Küçük L, Buzlu S (2018) Bir Toplum Ruh Sağlığı Merkezi'nde uygulanan rehabilitasyon programlarına katılan ve katılmayan şizofreni hastalarının bazı sosyodemografik ve hastalıkla ilişkili özellikleri ile tedaviye uyumları ve öz-yeterlilikleri açısından tanımlanması. J Psychiatric Nurs, 9:69-79.

Yang CY, Lee TH, Lo SC, Beckstead JW (2015) The effects of auditory hallucination symptom management programme for people with schizophrenia: A quasi-experimental design. J Adv Nurs, 71:2886-2897. 
Yang M, He H, Duan M, Chen X, Chang X, Lai Y et al. (2018) The effects of music Intervention on functional connectivity strength of the brain in schizophrenia. Neural Plast, 2018:2821832.

Yazııı A (2001) Şizofrenide Psikososyal Tedaviler: Şizofrenik Hastalarda Ruhsal Eğitim Grupları. İstanbul: Kutu Grafik.

Ye M, Guo J, Song C, Zheng F (2017) Effects of out-of-hospital continuing nursing on schizophrenia patients'sehabilitation and quality of life. Open Med, 12:501-505.

Yıldız M (2005) Şizofrenili hastaların ayaktan tedavisinde ruhsal ve toplumsal girişimler neden gereklidir ve nasıl uygulanabilir. In Neden Nasıl Şizofreni (Ed. S Candansayar): 237-268. Ankara, Peday Yayınları.

YıIdız M, Tural Ü, Kurdoğlu S, Önder ME (2003) Şizofreni rehabilitasyonunda aile ve gönüllülerle yürütülen bir kulüp-ev denemesi. Turk Psikiyatri Derg, 14:281-287.

Yıldız M, Yazıı A, Ünal S, Aker T, Özgen G, Ekmekçi H et al. (2002) Şizofreninin ruhsal-toplumsal tedavisinde sosyal beceri eğitimi: Belirtilerle başetme ve ilaç tedavisi yaklaşımının Türkiye'de çok merkezli bir uygulaması. Turk Psikiyatri Derg, 13:41-47.

Yazarların Katkıları: Yazarlar çalışmaya önemli bir bilimsel katkı sağladıklarını ve makalenin hazırlanmasında veya gözden geçirilmesinde yardımcı olduğunu kabul etmişlerdir.

Danışman Değerlendirmesi: Dış bağımsız.

Çıkar Çatışması: Yazarlar çıkar çatışması bildirmemiştir.

Finansal Destek: Yazarlar bu çalışma için finansal destek almadıklarııı beyan etmişlerdir.

Authors Contributions: The authors attest that she has made an important scientific contribution to the study and has assisted with the drafting or revising of the manuscript.

Peer-review: Externally peer-reviewed.

Conflict of Interest: No conflict of interest was declared by the authors.

Financial Disclosure: The authors declared that this study has received no financial support. 